\title{
Transfer of mercury from benthic invertebrates to fishes in lakes with contrasting fish community structures
}

\author{
Allan H.K. Wong, Donald J. McQueen, D. Dudley Williams, and Eric Demers
}

\begin{abstract}
We examined the flow of mercury $(\mathrm{Hg})$ from benthic invertebrates to fishes in lakes with contrasting fish community structure. The study was carried out in two whole lakes in southcentral Ontario in 1992. Both were remote from direct sources of contamination and were chosen because of their physical and chemical similarities. Although the fish communities in the two lakes were qualitatively similar, the total number of fishes in Ranger Lake was an order of magnitude smaller than that in Mouse Lake. As a result of the lower net predation from benthivorous fishes, documented in earlier studies, Ranger Lake benthic invertebrate populations were significantly higher. However, benthic invertebrate taxa in Mouse Lake were generally larger and had higher Hg concentrations. This was partly attributed to the stunted growth of Mouse Lake fishes, which did not allow them to prey on larger benthos as a result of gape limitations. Despite the lower Hg concentrations in Ranger Lake benthos, total benthic invertebrate $\mathrm{Hg}$ pools were higher in this lake as a result of its higher total benthic invertebrate biomass. However, the transfer of total $\mathrm{Hg}$ from benthic invertebrates to fishes was higher in Mouse Lake due to the higher consumption rates of benthivorous fishes.
\end{abstract}

\begin{abstract}
Résumé : Nous avons examiné le flux du mercure $(\mathrm{Hg})$ des invertébrés benthiques aux poissons dans des lacs ayant des communautés de poissons de structure différente. L'étude a été réalisée dans deux lacs entiers dans le centre-sud de l'Ontario en 1992. Les deux lacs étaient éloignés des sources de contamination directe et ils ont été choisis en raison de leur ressemblance du point de vue physique et chimique. Bien que les communautés de poissons dans les deux lacs aient été semblables du point de vue qualitatif, le nombre total de poissons dans le lac Ranger était inférieur d'un ordre de grandeur à celui du lac Mouse. À cause de la prédation nette inférieure attribuable aux poissons benthivores, documentée dans des études antérieures, les populations d'invertébrés benthiques du lac Ranger étaient substantiellement plus importantes. Cependant, les représentants des taxons d'invertébrés benthiques du lac Mouse étaient généralement de taille plus grande et avaient des concentrations de $\mathrm{Hg}$ plus élevées. Cette situation était en partie attribuable à la croissance arrêtée des poissons du lac Mouse, qui ne leur permettait pas de consommer les organismes benthiques plus gros en raison d'une ouverture maximale de la bouche insuffisante. Malgré les concentrations de $\mathrm{Hg}$ inférieures dans le benthos du lac Ranger, les pools de $\mathrm{Hg}$ chez les invertébrés benthiques étaient plus importants dans ce lac en raison de sa biomasse totale en invertébrés benthiques plus élevée. Toutefois, le transfert de Hg des invertébrés benthiques aux poissons était plus élevé dans le lac Mouse en raison du taux de consommation plus élevé des poissons benthivores.

[Traduit par la Rédaction]
\end{abstract}

\section{Introduction}

Many lakes in North America that have never received direct discharges of mercury-containing contaminants exhibit elevated levels of this metal (Evans 1986; Fitzgerald and Clarkson 1991). This has led to restrictions on the consumption of many species of fish (OMOE and OMNR 1991). Hg concentrations in biota can vary dramatically among uncontaminated lakes, and thus, many studies have attempted to determine possible environmental causes for these differences. With respect

Received February 27, 1996. Accepted November 18, 1996 $\mathrm{J} 13321$

A.H.K. Wong ${ }^{1}$ and D.D. Williams. Division of Life Sciences, University of Toronto at Scarborough, 1265 Military Trail, Scarborough, ON M1C 1A4, Canada.

D.J. McQueen and E. Demers. Department of Biology, York University, 4700 Keele Street, North York, ON M3J 1P3, Canada.

Author to whom all correspondence should be addressed. e-mail: alwong@lake.scar.utoronto.ca to fishes, it is generally believed that $\mathrm{Hg}$ bioaccumulation is enhanced by increased acidity (Wren and MacCrimmon 1983; Suns et al. 1987), increased dissolved organic matter (Suns et al. 1987; Mierle and Ingram 1991), decreased water hardness (Rodgers and Beamish 1983), and decreased alkalinity (Wiener and Stokes 1990; Spry and Wiener 1991).

Except for a few studies, ecological considerations generally have been ignored as possible factors that may influence contaminant bioaccumulation. Field studies have shown that $\mathrm{Hg}$ accumulation in fishes is highly influenced by diet (MacCrimmon et al. 1983; Mathers and Johansen 1985). Rasmussen et al. (1990) and Futter (1994) have found that food web structure can influence PCB and $\mathrm{Hg}$ concentrations, respectively, in top fish predators. In addition, when total fish populations have changed, fishes that occupy a lower trophic level also show changes in $\mathrm{Hg}$ accumulation as a result of shifts in diets and growth rates (Verta 1990). It is not known whether there is any between-lake variability in $\mathrm{Hg}$ accumulation among littoral zone biota resulting from differences in trophic structures. While there is no empirical evidence available, such differences are predicted to be significant (Rasmussen et al. 1990). 
Fig. 1. Bathymetric maps of Ranger and Mouse lakes. Depth intervals are indicated in metres. Arrows adjacent to lakes indicate inflows and outflows.
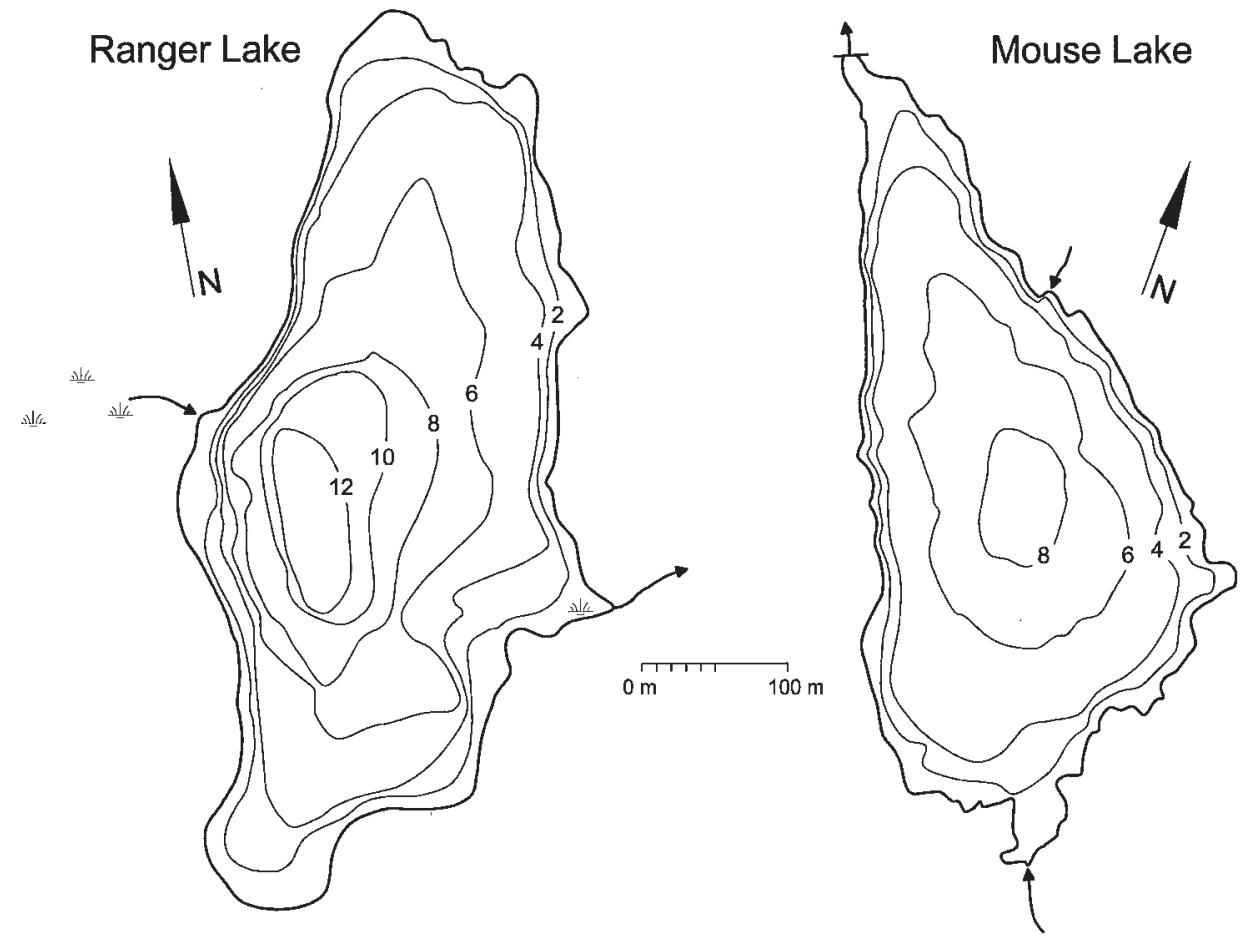

The purpose of this study was to determine whether contrasting fish community structures would affect benthic invertebrate $\mathrm{Hg}$ concentrations, benthic invertebrate $\mathrm{Hg}$ pools, and the flow of $\mathrm{Hg}$ from benthos to fishes. Since invertebrate size is correlated with $\mathrm{Hg}$ concentrations, $\mathrm{Hg}$ accumulation in benthic invertebrates may be affected as a result of decreased size caused by predatory stress (Feltmate and Williams 1991; Parkman and Meili 1993). Conversely, $\mathrm{Hg}$ bioaccumulation in fish predators also can be affected because of differences in available diet (MacCrimmon et al. 1983). Although the pool of $\mathrm{Hg}$ found in benthic invertebrates may not necessarily reflect the amount of $\mathrm{Hg}$ consumed by benthivorous fishes, it can be helpful as a measure of the cycling of $\mathrm{Hg}$. Mouse Lake and Ranger Lake were chosen for this study because of their contrasting fish trophic structures, although the species of fishes present in the two lakes were similar (Rocchi 1993; Popiel 1994; Ramcharan et al. 1995). Furthermore, the physical and chemical similarities between the two lakes diminish the possibilities of differences in $\mathrm{Hg}$ accumulation by influences other than fish community structure (Ramcharan et al. 1995).

\section{Study site description}

Mouse Lake $\left(45^{\circ} 11^{\prime} \mathrm{N}, 78^{\circ} 5^{\prime} \mathrm{W}\right)$ and Ranger Lake $\left(45^{\circ} 09^{\prime} \mathrm{N}\right.$, $78^{\circ} 51^{\prime} \mathrm{W}$ ) are located in the Muskoka region of southcentral Ontario (Fig. 1). Mouse and Ranger lakes have surface areas of 9.0 and 11.2 ha and maximum depths of 9.0 and $13.0 \mathrm{~m}$, respectively. In addition, their water chemistries are very similar (Table 1) (Ramcharan et al. 1995). Brasenia sp., Pontederia sp., and Potamogeton sp. are the dominant macrophytes present in the two lakes.

The total $\mathrm{Hg}$ concentrations in the water column in Mouse and Ranger lakes were $1.52(n=6)$ and $2.19 \mathrm{ng} / \mathrm{L}(n=7)$, respectively (Table 1$)$. In the shallow zone $(<1.0 \mathrm{~m})$ the total $\mathrm{Hg}$ concentrations in sediments in Mouse and Ranger lakes were $28.1(n=12)$ and $29.3 \mathrm{ng} / \mathrm{g}$ dry weight $(\mathrm{dw})(n=12)$, respectively. In the 1.0-4.9 m depth zone, total $\mathrm{Hg}$ concentrations in sediments were $84.9(n=3)$ and $70.8 \mathrm{ng} / \mathrm{g} \mathrm{dw}(n=3)$ in Mouse and Ranger lakes, respectively. In the deepest zone (5.0-9.0 m), total $\mathrm{Hg}$ concentrations in sediments in Mouse Lake (281.8 ng/g dw, $n=3$ ) and Ranger Lake (310.8 ng/g dw, $n=3$ ) were also similar.

The major fish species present in Mouse and Ranger lakes were alike (Table 2). They included pumpkinseed (Lepomis gibbosus), yellow perch (Perca flavescens), and white sucker (Catostomus commersoni). However, the presence of piscivores (smallmouth bass (Micropterus dolomieu) and largemouth bass (M. salmoides)) in Ranger Lake led to a total fish population (282 fish/ha) that was an order of magnitude smaller than that in Mouse Lake (2152 fish/ha) (Ramcharan et al. 1995). Although the benthivorous fish (yellow perch and pumpkinseed) diets in the two lakes were qualitatively similar (Rocchi 1993; Popiel 1994), the net predation of the benthos was much higher in Mouse Lake because of the higher fish population (Wong 1995). The rate of consumption of benthic invertebrates during the study period by all fishes in Mouse Lake was between 1.5 (July) and 2.7 (August) times greater than in Ranger Lake (Wong 1995). As a result, the total benthic biomass in Ranger Lake was consistently higher than in Mouse Lake at depths $<1.0 \mathrm{~m}$.

\section{Methods}

Benthic survey

Benthic invertebrates were collected during June, July, and August 
Table 1. Physical and chemical characteristics of Mouse and Ranger lakes, 1992 (1993 and 1994 for sediment and water $\mathrm{Hg}$ data, respectively).

\begin{tabular}{|c|c|c|}
\hline Physical/chemical parameter & Mouse & Ranger \\
\hline$\overline{\text { Catchment area (ha) }}$ & 185 & 260 \\
\hline Surface area (ha) & 8.99 & 11.25 \\
\hline Volume $\left(\mathrm{m}^{3} \times 10^{5}\right)$ & 4.39 & 6.32 \\
\hline Flushing rate (year $\left.{ }^{-1}\right)$ & 2.41 & 2.32 \\
\hline Maximum depth (m) & 9.0 & 13.0 \\
\hline Mean depth (m) & 4.88 & 5.62 \\
\hline Shoreline length $(\mathrm{km})$ & 1.59 & 1.63 \\
\hline Shoreline development & 1.50 & 1.37 \\
\hline $\mathrm{pH}$ (epilimnion) & $5.62(0.052)$ & $6.01(0.068)$ \\
\hline $\mathrm{pH}$ (metalimnion) & $5.44(0.055)$ & $5.64(0.035)$ \\
\hline pH (hypolimnion) & $5.59(0.055)$ & $5.83(0.050)$ \\
\hline $\mathrm{DIC}(\mathrm{mg} / \mathrm{L})$ & $0.68(0.215)$ & $0.54(0.083)$ \\
\hline $\mathrm{DOC}(\mathrm{mg} / \mathrm{L})$ & $4.67(0.198)$ & $4.91(0.224)$ \\
\hline Total alkalinity (mequiv./L) & $0.28(0.0965)$ & $0.62(0.0431)$ \\
\hline Total iron $(\mu \mathrm{g} / \mathrm{L})$ & $0.0022(0.00044)$ & $0.0017(0.00044)$ \\
\hline Total nitrogen $(\mu \mathrm{g} / \mathrm{L})$ & $295.0(11.9)$ & $284.0(9.9)$ \\
\hline Total phosphorus $(\mu \mathrm{g} / \mathrm{L})$ & $7.80(0.58)$ & $5.91(0.34)$ \\
\hline $\mathrm{Ca}^{2+}$ (mequiv./L) & $0.029(0.00019)$ & $0.031(0.00033)$ \\
\hline $\mathrm{Mg}^{2+}$ (mequiv./L) & $0.0252(0.00019)$ & $0.0289(0.00028)$ \\
\hline Total Hg, water (ng/L) & $1.52(0.06)$ & $2.19(0.10)$ \\
\hline Total $\mathrm{Hg}$, sediment $(<1 \mathrm{~m})(\mathrm{ng} / \mathrm{g} \mathrm{dw})$ & $28.10(9.23)$ & $29.31(16.40)$ \\
\hline Total $\mathrm{Hg}$, sediment $(1-4.9 \mathrm{~m})(\mathrm{ng} / \mathrm{g} \mathrm{dw})$ & $84.90(23.41)$ & $70.83(57.14)$ \\
\hline Total Hg, sediment (5-9 m) (ng/g dw) & $281.82(16.06)$ & $310.89(6.44)$ \\
\hline
\end{tabular}

Note: Chemical values (with the exception of sediment $\mathrm{Hg}$ data) are seasonal epilimnetic means. Standard errors are given in parentheses. Adapted from Ramcharan et al. (1995) and D.J. McQueen et al., unpublished data.

Table 2. Fish abundance and biomass ( $\pm 95 \%$ confidence interval) in Mouse and Ranger lakes, 1992.

\begin{tabular}{|c|c|c|c|c|}
\hline \multirow[b]{2}{*}{ Fish species } & \multicolumn{2}{|c|}{ Abundance (no./ha) } & \multicolumn{2}{|c|}{ Biomass (kg/ha) } \\
\hline & Mouse & Ranger & Mouse & Ranger \\
\hline Largemouth bass (Micropterus salmoides) & 0 & $48.3(18.7-125.6)$ & 0 & $4.4(1.7-11.4)$ \\
\hline Yellow perch (Perca flavescens) & $594.4(459.8-768.4)$ & $2.3(1.2-4.6)$ & $7.1(5.5-9.1)$ & $0.2(0.1-0.5)$ \\
\hline Pumpkinseed (Lepomis gibbosus) & $1233.0(890.6-1707.3)$ & $161.4(113.5-228.5)$ & $10.8(7.8-14.9)$ & $4.7(3.3-6.6)$ \\
\hline White sucker (Catostomus commersoni) & $31.7(21.9-458)$ & $57.4(52.7-62.4)$ & $16.2(11.2-23.4)$ & $18.7(17.2-20.3)$ \\
\hline Creek chub (Semotilus atromaculatus) & $50.1(74.5-174.4)$ & - & $0.6(0.4-0.9)$ & - \\
\hline
\end{tabular}

Note: Dashes indicate species of fishes that were present but either not tagged or not recaptured. Adapted from Ramcharan et al. (1995).

1992 from Mouse and Ranger lakes. Approximately 60 benthic samples were collected from each lake during each of these months. Because of the higher benthic populations and benthivorous fish activity recorded in the shallow depth zone (defined as $<1.0 \mathrm{~m}$ ) (Post and Cucin 1984; N.C. Collins, Erindale Campus, University of Toronto, Toronto, Ont., personal communication), greater sampling effort $(60 \%)$ was devoted to this depth interval. The proportion of lake area occupied by each depth zone $>1.0 \mathrm{~m}$ was then used to stratify the remaining sampling effort. These depth intervals were $1.0-4.9$ and 5.0-9.0 m. Sampling sites within each depth zone were chosen at random.

A metal corer with an internal area of $91 \mathrm{~cm}^{2}$ (sample depth $\sim 10 \mathrm{~cm})$ was used to obtain shallow samples $(<1.0 \mathrm{~m})$. Deeper samples (i.e., $>1.0 \mathrm{~m}$ ) were obtained with an Ekman dredge that had a surface area of $225 \mathrm{~cm}^{2}$ (sample depth $\sim 20 \mathrm{~cm}$ ). Two sieves of 53and $200-\mu \mathrm{m}$ mesh were used to filter the shallow and deep samples, respectively, because the sediment particle size and volume differed at the various depths. Samples were preserved in $10 \%$ formalin solution and stained with rose bengal in the field. The samples were processed by centrifugally floating with saturated $\mathrm{CaCl}_{2}$ to remove sand and cobble (Cromar and Williams 1991). The organisms were then sorted under a dissecting microscope (at 10× magnification) and stored in $70 \%$ ethanol. Identification was done using the taxonomic keys in Merritt and Cummins (1978).

A Metler microbalance was used to weigh organisms to the nearest $1 \mu \mathrm{g}$ immediately after blotting them to remove excess fluid. Weights of individual taxa were obtained by pooling the weights of specimens of each taxon from a single sample. A subset of samples was also dry weighed. Dry weights for all other samples were obtained by multiplying wet weights with taxon-specific conversion factors that varied from 0.09 to 0.22 (Wong 1995). These taxon-specific conversion factors were averages of the ratio of dry weight to wet weight. All benthic masses presented represent dry weights, unless otherwise stated. Mean individual weights were obtained by dividing the pooled taxon weight by the total number of individuals in that sample.

\section{Hg determination}

A separate set of benthic invertebrates was collected from Mouse and 
Ranger lakes for $\mathrm{Hg}$ analysis. Samples were collected from all depths (i.e., < 1.0, 1.0-4.9, and 5.0-9.0 m). Collections were made with a dip net in the shallow zone and a stainless steel Ekman dredge in the deeper zones and then filtered through $200-\mu \mathrm{m}$ Nitex sieves. Organisms were sorted alive (according to taxon) with clean plastic forceps and trays and then set in a refrigerator for $48 \mathrm{~h}$ to purge their stomachs of their contents (Jackson 1988). The organisms were subsequently placed in scintillation vials that were covered with parafilm and placed in Zip-Loc polyethylene bags and frozen for later analysis.

Total $\mathrm{Hg}$ was measured through cold vapour atomic absorption spectrophotometry with a Pharmacia mercury monitor, model $100 \mathrm{M}$ (Allard and Stokes 1989). Benthic samples were dried at $60^{\circ} \mathrm{C}$ for $48 \mathrm{~h}$ and then weighed (minimum weight $\approx 5 \mathrm{mg} \mathrm{dw}$ ). Samples were digested in $2.0 \mathrm{~mL}$ of a 1:4 $\mathrm{HNO}_{3}$ (BDH AnalaR) $-\mathrm{H}_{2} \mathrm{SO}_{4}$ (Seastar) mixture at $250^{\circ} \mathrm{C}$ for $6 \mathrm{~h}$ and then diluted with ultrapure water upon cooling to room temperature. The following day, $1.5 \mathrm{~mL}$ of hydroxylamine hydrochloride $(10 \%)$ was added to each sample. One hundred and fifty millilitres of $15 \%$ stannous chloride (in $10 \% \mathrm{HCl}$ ) was used as the reductant in the final $\mathrm{Hg}$ analysis.

\section{Quality assurance/quality control}

To avoid contamination of samples, plastic forceps, plastic sorting trays, scintillation vials, and glassware were all thoroughly cleaned with soap and ultrapure water. This was followed by bathing sequentially in $1 \mathrm{M} \mathrm{NaOH}$ and $10 \% \mathrm{HNO}_{3}$ for $24 \mathrm{~h}$ each. All standards, reagents, dilutions, and glassware were prepared with deionized and double-distilled water.

Total $\mathrm{Hg}$ analyses for individual samples were repeated three times or until the peaks varied by no more than $5 \%$. Triplicates of blanks, spiked samples, standard solutions $(0.0,0.1,0.5$, and $1.0 \mathrm{ng}$ $\mathrm{Hg} / \mathrm{L}$ ), and Canadian National Research Council dogfish muscle (Dorm-1) (certified $0.798 \mathrm{mg} \mathrm{Hg} / \mathrm{kg}$ ) were analyzed at the beginning of each batch of samples. Standard solutions of $1.0 \mathrm{ng} \mathrm{Hg} / \mathrm{mL}$ were analyzed throughout each batch (i.e., every third sample) to ensure accuracy and precision throughout analysis of each batch of samples. The mean $( \pm \mathrm{SE})$ recovery of Dorm-1 from 27 batches of samples was $99.8 \%( \pm 2.22)$, with a range of $75-110 \%$. The reported $95 \%$ confidence limits for the Dorm- 1 were $\pm 9 \%$. The two batches of National Institute of Standards and Technology sediment standards (No. 8406, reported value of $0.06 \mu \mathrm{g} / \mathrm{g}$ ) had a recovery level $( \pm \mathrm{SE})$ of $85.0 \%$ ( \pm 1.6$)$. No reported confidence limits were provided for the sediment standards. The recovery $( \pm \mathrm{SE})$ of spiked samples from 27 batches averaged $95.5 \%( \pm 2.1)$, with a range of $73.9-112.4 \%$. Further details of the laboratory setup and conditions are described in Mierle (1990).

\section{Statistical analyses}

One-way repeated measures analysis of variance (RMANOVA) and standard one-way ANOVA were used to test for differences between mean benthic biomass (grams per square metre) and $\mathrm{Hg}$ concentrations (nanograms per gram) between Mouse and Ranger lakes, respectively. $\log (x+1)$ transformations were performed on the data to achieve homogeneity of variances and normality. Data are presented in an untransformed state, unless otherwise stated. $\mathrm{Hg}$ pools (nanograms per square metre) were estimated by multiplying Hg concentration (nanograms per gram) by the mean biomass (grams per square metre) for each taxon. Note that dry weights and dry Hg concentrations were used for statistical purposes. All statistical analyses were done using the Statistical Analysis System (SAS Institute, Inc. 1982).

\section{Hg consumption analyses}

Fish populations were estimated by mark and recapture during May-September 1992 by trap-netting, beach-seining, electrofishing, and hook and line (Ramcharan et al. 1995). Cohort estimates were determined for each species by recording physical parameters (length, weight, and scales) of fishes. Detailed analyses of fish diets were obtained by purging stomach contents. All benthos were identified using keys in Merritt and Cummins (1978) and wet weighed. Fish consumption rates, based on calculations from measured growth, were estimated using the Hewett and Johnson (1992) fish bioenergetics model. Total $\mathrm{Hg}$ consumption rates for each species were calculated by multiplying the consumption rates for each benthic invertebrate taxon by their corresponding $\mathrm{Hg}$ concentration.

\section{Results}

The total estimated benthic invertebrate biomass in the shallow zone (i.e., $<1.0 \mathrm{~m}$ ) was significantly higher in Ranger Lake (one-way RMANOVA, $F=4.5, p=0.04$ ) compared with Mouse Lake (Table 3). This corresponded to total benthic biomasses in Ranger Lake that were up to 1.5 times (June) higher than in Mouse Lake. A large proportion of the total benthic biomass from each lake consisted of the Odonata, Chironomidae (larvae), Gastropoda, and Ephemeroptera (in descending order of importance).

In the 1.0-4.9 $\mathrm{m}$ depth zone, total benthic biomasses between the two lakes were not statistically different during the three months of the study (one-way RMANOVA, $F=0.28$, $p=0.60$ ) (Table 3). In the 5.0-9.0 m depth zone, the total benthic biomasses were significantly higher in Ranger Lake (oneway RMANOVA, $F=27.3, p=0.0001$ ) (Table 3 ). This resulted in benthic biomasses in Ranger Lake that were 2.4 and 4.3 times higher than in Mouse Lake in July and August, respectively. A large proportion (usually $>95 \%$ ) of the benthic biomass in the 5.0-9.0 m samples comprised chironomid (primarily Chironomus spp.) and chaoborid (Chaoborus spp.) larvae.

Mean individual weights of benthos were significantly different between the two lakes (one-way RMANOVA, $p<0.05$ ) (Table 4). All significant tests indicated that Mouse Lake had larger individuals. This included the Gastropoda $(F=28.8, p=$ $0.0001)$, Chironomidae larvae $(F=25.1, p=0.0001)$, and Ephemeroptera $(F=19.6, p=0.0003)$.

A total of 704 benthic invertebrate samples were measured for total $\mathrm{Hg}$ in the two lakes (Table 5). Each sample consisted of several individual specimens of the same taxon combined, except for the Odonata and Gastropoda (and the larger Ephemeroptera and Trichoptera), which were analyzed as individual specimens. In both Mouse and Ranger lakes the lowest $\mathrm{Hg}$ concentrations were found in the chaoborid and trichopteran larvae where total $\mathrm{Hg}$ concentrations were $<100 \mathrm{ng} / \mathrm{g} \mathrm{dw}$ for both taxa. The highest total $\mathrm{Hg}$ concentration was found in the gastropod Campeloma decisum in both Mouse Lake (938 ng/g dw) and Ranger Lake (609 ng/g dw). The Mouse Lake Gastropoda (one-way ANOVA, $p=0.02$ ), shallow $(<1.0 \mathrm{~m})$ Chironomidae $(p=0.001)$, and Odonata $(p=$ $0.0002)$ all had significantly higher $\mathrm{Hg}$ concentrations than their Ranger Lake equivalents.

Despite the generally higher concentrations of $\mathrm{Hg}$ in benthic invertebrates from Mouse Lake, the benthic invertebrate $\mathrm{Hg}$ pools in Ranger Lake were significantly higher (one-way RMANOVA, $F=10.3, p=0.0002$ ) at depths of $<1.0 \mathrm{~m}$ (Fig. 2). The amounts by which they were higher in Ranger Lake than in Mouse Lake were 0.5 (August) to 2.7 (July). In the 5.0-9.0 m depth zone, the benthic Hg pool in Ranger Lake was up to 3.9 times higher (August) than in Mouse Lake. The chironomid larvae consistently had the highest geometric mean $\mathrm{Hg}$ pools at all depths in both lakes. They ranged from 
Table 3. Mean benthic biomasses $\left(\mathrm{g} / \mathrm{m}^{2} \mathrm{dw}\right)$ and standard errors (in parentheses) for benthic invertebrates in all depth zones $(<1.0,1-4.9$, and 5-9 m) of Mouse and Ranger lakes, 1992.

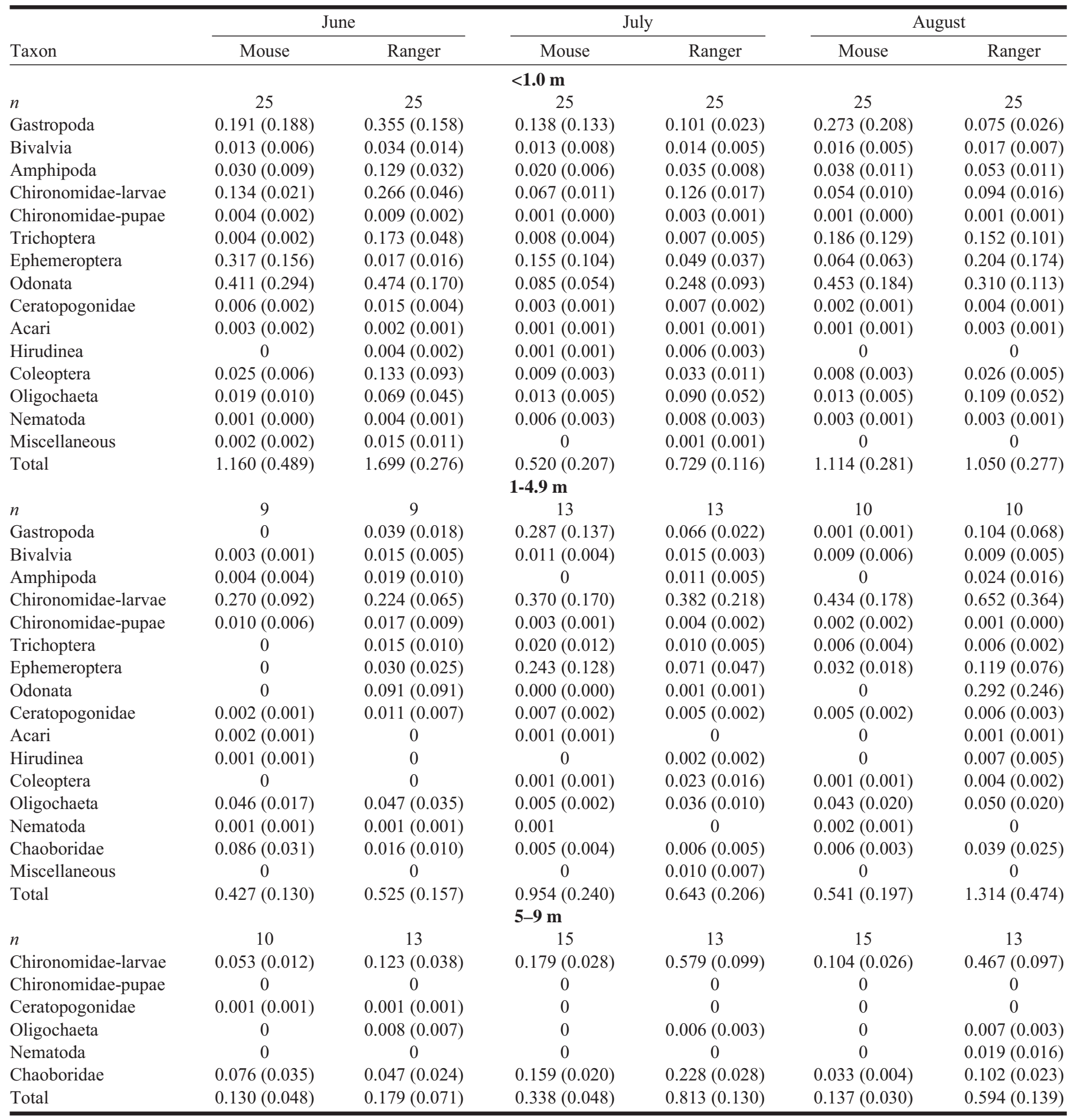

approximately 10 to $50 \mathrm{ng} / \mathrm{m}^{2}$, with higher values generally found in Ranger Lake. Other taxa that had high $\mathrm{Hg}$ pools were the Gastropoda, Odonata, and Ephemeroptera (Table 6).

Fish consumption modeling throughout the summer of 1992 revealed that the monthly transfer of $\mathrm{Hg}$ from benthic invertebrates to fishes was consistently higher in Mouse Lake, in comparison with Ranger Lake. The total amount of Hg consumed by all benthivorous fishes from 1 June 1992 to 31 August
1992 was 614.3 and $515.6 \mu \mathrm{g} / \mathrm{ha}$ in Mouse and Ranger lakes, respectively (Figs. 3 and 4). When the consumption rates of $\mathrm{Hg}$ were analyzed without the white suckers, the differences between the two lakes were even greater. That is, cumulative $\mathrm{Hg}$ consumption for Mouse and Ranger lakes was 356.3 and $132.2 \mu \mathrm{g} / \mathrm{ha}$, respectively. The consumption rates of $\mathrm{Hg}$ by fishes via benthos ranged from 2.3 (July) to 3.6 times higher (August) in Mouse Lake. 
Table 4. Mean individual wet mass (mg) (standard error in parentheses) for Mouse and Ranger Lake Gastropoda, Amphipoda, Chironomidae, Trichoptera, Ephemeroptera, and Odonata from June to August 1992.

\begin{tabular}{|c|c|c|c|c|c|c|c|c|c|c|c|c|c|}
\hline Month & Lake & Gastr & $n$ & Amphipoda & $n$ & Chironomidae* & $n$ & Trichoptera & $n$ & Ephemeroptera* & $n$ & Odonata & $n$ \\
\hline \multirow[t]{2}{*}{ June } & ou & 5 & 4 & $1.2^{\prime}$ & 14 & 24 & 25 & 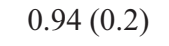 & 6 & 55. & 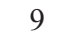 & 58.9 & 11 \\
\hline & & & 19 & & 19 & & 25 & 10. & 14 & & 12 & 7) & 16 \\
\hline July & Mouse & 60.0 & 4 & 0.7 & 19 & & 25 & 1.0 & 7 & & 11 & 18.7 & 5 \\
\hline \multirow[t]{2}{*}{ August } & Mouse & $99.1(124.4)$ & 3 & $0.60(0.1)$ & 21 & $0.39(0.5)$ & 25 & $68.3(39.5)$ & 4 & $6.2(5.8)$ & 9 & $51.2(22.7)$ & 11 \\
\hline & Ranger & $2.2(0.34)$ & 19 & $0.46(0.04)$ & 24 & $0.01(0.01)$ & 25 & $6.8(5.5)$ & 13 & $1.88(1.0)$ & 20 & $14.5(4.4)$ & 15 \\
\hline
\end{tabular}

Note: Number of samples $=n$. Significant between-lake differences are indicated by an asterisk (one-way RMANOVA, $p<0.05$ ).

Table 5. Total Hg concentrations (ng/g dw) for all benthic invertebrates in Mouse and Ranger lakes, 1992.

\begin{tabular}{lccccc}
\hline Taxon & Mouse & $n$ & Ranger & $n$ & $p$ \\
\hline Gastropoda & $938.7(92.0)$ & 49 & $609.9(53.4)$ & 21 & $<0.05$ \\
Amphipoda & $98.2(22.9)$ & 17 & $157.6(20.4)$ & 24 & $>0.05$ \\
Chironomidae $(<1 \mathrm{~m})$ & $177.2(18.1)$ & 33 & $110.3(9.7)$ & 41 & $<0.005$ \\
Chironomidae $(1-4.9 \mathrm{~m})$ & $116.4(9.0)$ & 14 & $131.1(19.3)$ & 47 & $>0.05$ \\
Chironomidae $(5-9 \mathrm{~m})$ & $97.2(17.1)$ & 36 & $132.9(12.4)$ & 33 & $>0.1$ \\
Chaoboridae & $73.9(10.4)$ & 12 & $82.4(18.7)$ & 22 & $>0.05$ \\
Trichoptera & $92.4(9.6)$ & 27 & $70.5(7.6)$ & 20 & $>0.05$ \\
Ephemeroptera & $151.0(16.2)$ & 15 & $128.4(17.2)$ & 12 & $>0.1$ \\
Odonata & $135.7(4.5)$ & 158 & $112.7(3.7)$ & 117 & $<0.001$ \\
Ceratopogonidae & $162.4(31.0)$ & 3 & $99.7(2.4)$ & 2 & $>0.1$ \\
Coleoptera & - & & $206.4(56.0)$ & 9 & $\mathrm{n} / \mathrm{a}$ \\
Oligochaeta & - & & $163.7(2.0)$ & 2 & $\mathrm{n} / \mathrm{a}$ \\
Miscellaneous & $156.7(18.1)$ & & $120.6(9.7)$ & & $\mathrm{n} / \mathrm{a}$ \\
\hline
\end{tabular}

Note: Separate $\mathrm{Hg}$ concentrations were obtained for the Chironomidae at each depth interval (i.e., $<1,1-4.9$, and 5-9 m). The miscellaneous category represents a combination of rarer taxa (Bivalvia, Coleoptera, Acari, Oligochaeta, and Nematoda in Mouse Lake and Bivalvia, Acari, and Nematoda in Ranger Lake) that individually did not have sufficient biomasses for the $\mathrm{Hg}$ analysis. Dashes indicate taxa that were included in miscellaneous benthos. $p$-values from one-way ANOVA between lakes are included, with the exception of some taxa that were not available (n/a).

\section{Discussion}

Our results indicate that differences exist in $\mathrm{Hg}$ concentrations and $\mathrm{Hg}$ pools for benthic invertebrates in lakes with differing fish community structures. The benthic invertebrate $\mathrm{Hg}$ concentrations in the lake without piscivores but high numbers of benthivores (Mouse Lake) were generally higher than those in the lake containing piscivores and few benthivores (Ranger Lake), although there were exceptions (i.e., Amphipoda and deeper-water Chironomidae and Chaoboridae). Most noteworthy was the higher total $\mathrm{Hg}$ consumption by Mouse Lake fishes via benthos, resulting from their higher consumption rates.

It is not likely that chemical factors influenced the differences in total $\mathrm{Hg}$ concentrations in benthic invertebrates between Mouse and Ranger lakes. There were, however, two critical chemical parameters that displayed slight differences and that should be addressed. The epilimnetic $\mathrm{pH}$ in Mouse and Ranger lakes was 5.62 and 6.01, respectively, and the alkalinity was 0.28 and 0.62 mequiv./L, respectively.

It is conceivable that the lower levels of $\mathrm{pH}$ and alkalinity found in Mouse Lake, factors that are known to enhance $\mathrm{Hg}$ levels in fishes (Suns et al. 1987; Spry and Wiener 1991), contributed to the higher $\mathrm{Hg}$ concentrations measured in the Mouse Lake benthic invertebrates. However, the same mechanism of enhancing $\mathrm{Hg}$ levels in fishes under these conditions cannot explain the differences in $\mathrm{Hg}$ concentrations in deeperwater $(>1.0 \mathrm{~m})$ benthos between the two lakes. That is, Mouse Lake $\mathrm{pH}$ and alkalinity levels were also lower than Ranger Lake values in the deeper zones (i.e., 1.0-4.9 and 5.0-9.0 m) (Ramcharan et al. 1995), yet Hg concentrations in these chironomid larvae (primarily Chironomus, the only taxon found at all depth intervals) were not statistically different between the two lakes. In fact, in the deeper-water comparisons, the Ranger Lake chironomid $\mathrm{Hg}$ concentrations were slightly higher than in their Mouse Lake equivalents. However, this may only mean that $\mathrm{Hg}$ accumulation in chironomids is less sensitive to $\mathrm{pH}$ than in other invertebrates.

Although there is evidence that $\mathrm{Hg}$ levels in some fishes from localized watersheds are correlated with acidity (e.g., Wren and MacCrimmon 1983; Suns et al. 1987), it has not been established whether $\mathrm{Hg}$ concentrations in freshwater invertebrates are actually higher in lakes with lower $\mathrm{pH}$ (Wren and Stephenson 1991). Studies on the effects of $\mathrm{pH}$ on $\mathrm{Hg}$ concentrations in invertebrates are scarce and conflicting. In an experimentally acidified lake, France (1987) found that $\mathrm{Hg}$ levels in crayfish abdominal muscles were $0.52 \mu \mathrm{g} / \mathrm{g} \mathrm{dw}$ compared with $0.27 \mu \mathrm{g} / \mathrm{g} d w$ in nearby reference lakes. Similarly, in a survey of 13 lakes in southcentral Ontario, 54\% of the variability in $\mathrm{Hg}$ levels in crayfish abdominal muscles among lakes was explained by conductivity, which was highly correlated 
with lake pH (Allard and Stokes 1989). In contrast, Hg concentrations in composite insect samples from acidified $(\mathrm{pH} \sim$ 5.0) and nonacidified $(\mathrm{pH} \sim 6.5)$ constructed wetlands were not significantly different (Albers and Camardese 1993). Insects from the composite samples included Coleoptera, Diptera, Ephemeroptera, Hemiptera, Megaloptera, and Odonata. Additionally, a survey of 17 Muskoka area lakes in which $\mathrm{pH}$ ranged from 4.8 to 6.4 indicated that $\mathrm{Hg}$ concentrations in leeches (Macrobdella decora and Percymoorensis marmoratis) were not correlated with lake $\mathrm{pH}$ (McNicol et al. 1996). In eight remote lakes in Sweden, Hg concentrations in the tissues of some taxa showed an increase with decreasing $\mathrm{pH}$ whereas most macroinvertebrates surveyed did not show such a correlation (Parkman and Meili 1993). The scarcity and inconsistency of such data on the effect of $\mathrm{pH}$ on $\mathrm{Hg}$ concentrations in benthic invertebrates do not allow generalizations to be made with confidence (Campbell and Stokes 1985; Wren and Stephenson 1991).

The positive correlation between dissolved organic carbon (DOC) and $\mathrm{Hg}$ accumulation in fishes has received much attention (Suns et al. 1987; Wren et al. 1991). It is believed that humic material (as indicated by DOC concentrations) serves to promote methylation of mercury (Bodaly et al. 1984), and thus, increased humic material will act as an added source of methylmercury (MeHg) in aquatic environments (Mierle 1990). Conversely, Miskimmin et al. (1992) found that increased DOC concentrations led to decreased rates of methylation. The decrease in methylation was believed to be a result of inorganic $\mathrm{Hg}$ ions binding with DOC (Miskimmin et al. 1992). Although the effect of DOC on $\mathrm{Hg}$ accumulation in invertebrates is not well known (Allard and Stokes 1989), the nearly identical DOC levels in Mouse Lake $(4.67 \mu \mathrm{g} / \mathrm{L})$ and Ranger Lake $(4.91 \mu \mathrm{g} / \mathrm{L})$ preclude the likelihood of this factor contributing to the observed differences in $\mathrm{Hg}$ concentrations in the benthos of the two lakes. The similarities in water chemistry are further reflected in the nearly identical total $\mathrm{Hg}$ concentrations in the water column and sediments (at all three depth zones) of the two lakes.

Although much attention has been focused on physical and chemical variables in an attempt to explain among-lake variability in contaminant concentrations, relatively little interest has been shown in terms of differences in biotic factors such as food web structure. Some studies have shown that habitat and food selection are important factors in determining $\mathrm{Hg}$ concentrations in aquatic invertebrates (Armstrong and Hamilton 1974; Särkkä 1979; Parkman and Meili 1993). This would suggest that food web structure is an important factor in accounting for variability in contaminant concentrations as $\mathrm{Hg}$ is biomagnified up the food chain (Armstrong and Hamilton 1974). Although the effect of littoral zone trophic structure on $\mathrm{Hg}$ accumulation is not known, it is believed to be significant (Rasmussen et al. 1990).

Although Hg pools were higher in Ranger Lake, Hg concentrations were generally higher in Mouse Lake benthos. The higher Hg concentrations in Mouse Lake benthos were likely a consequence of fishes selectively consuming smaller benthos and leaving the larger benthos. The higher fish populations in Mouse Lake led to stunted growth in fishes in relation to Ranger Lake equivalents (Rocchi 1993; Popiel 1994). Consequently, the fishes in Mouse Lake were precluded from consuming larger prey because of gape limitations. This was
Fig. 2. Total benthic invertebrate mercury pools for Mouse Lake and Ranger Lake in the depth zones (A) <1.0, (B) 1.0-4.9, and (C) 5.0-9.0 m during June, July, and August 1992. Horizontal lines represent geometric means. Note that the $y$-axis is presented on a $\log$ scale. A value of 1 was added to each data point to facilitate plotting of all zero values. Each data point represents a $\mathrm{Hg}$ pool value that includes all benthos, based on calculations from the biomass of each sample.
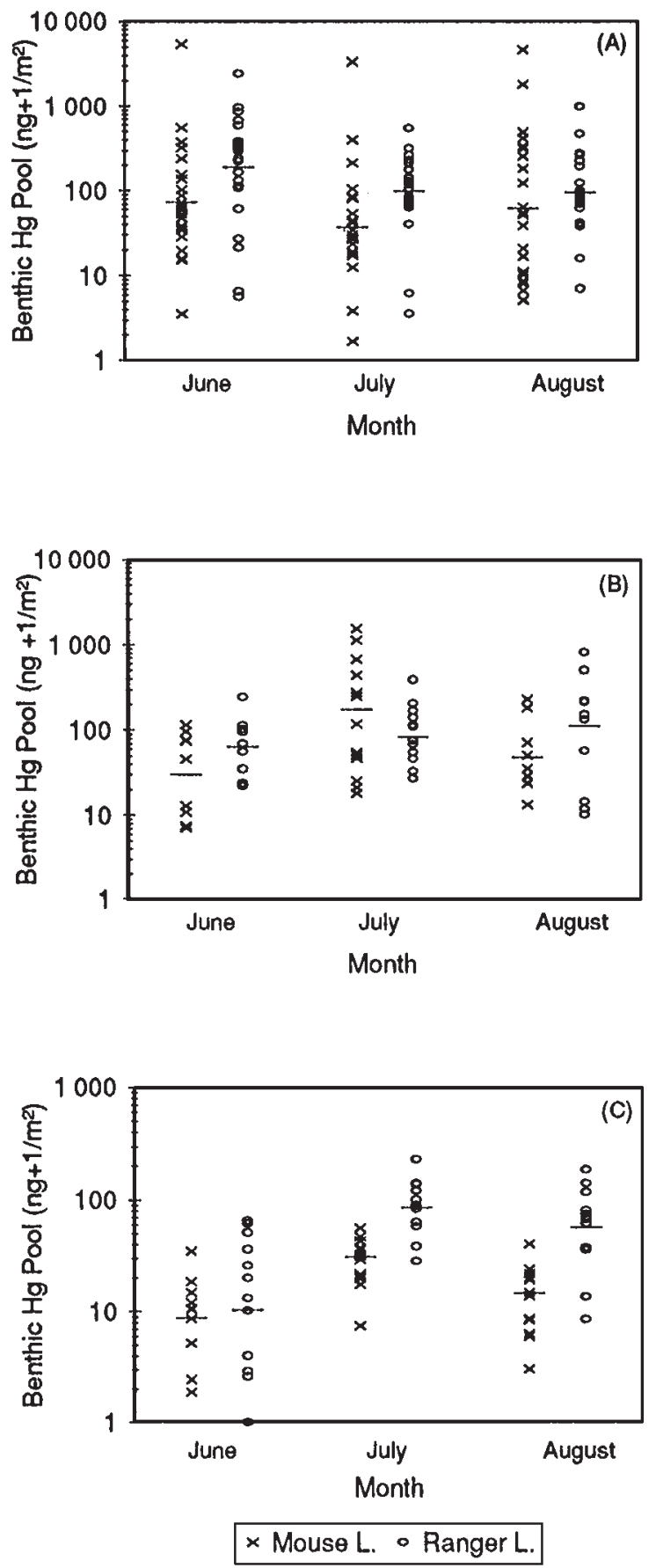

corroborated through experimental studies that showed that Mouse lake fishes were less effective at consuming prey because of gape restrictions (N.C. Collins, Department of Zoology, University of Toronto, Toronto, Ont., personal communication). 
Table 6. Mean $\mathrm{Hg}$ pool $\left(\mathrm{ng} / \mathrm{m}^{2}\right)$ per taxon and $95 \%$ confidence intervals (in parentheses) for benthic invertebrates in all depth zones (i.e., $<1.0$, 1-4.9, and 5-9 m) of Mouse and Ranger lakes, 1992 (geometric means obtained from back-transformations of logarithmic means (Sokal and Rohlf 1981)).

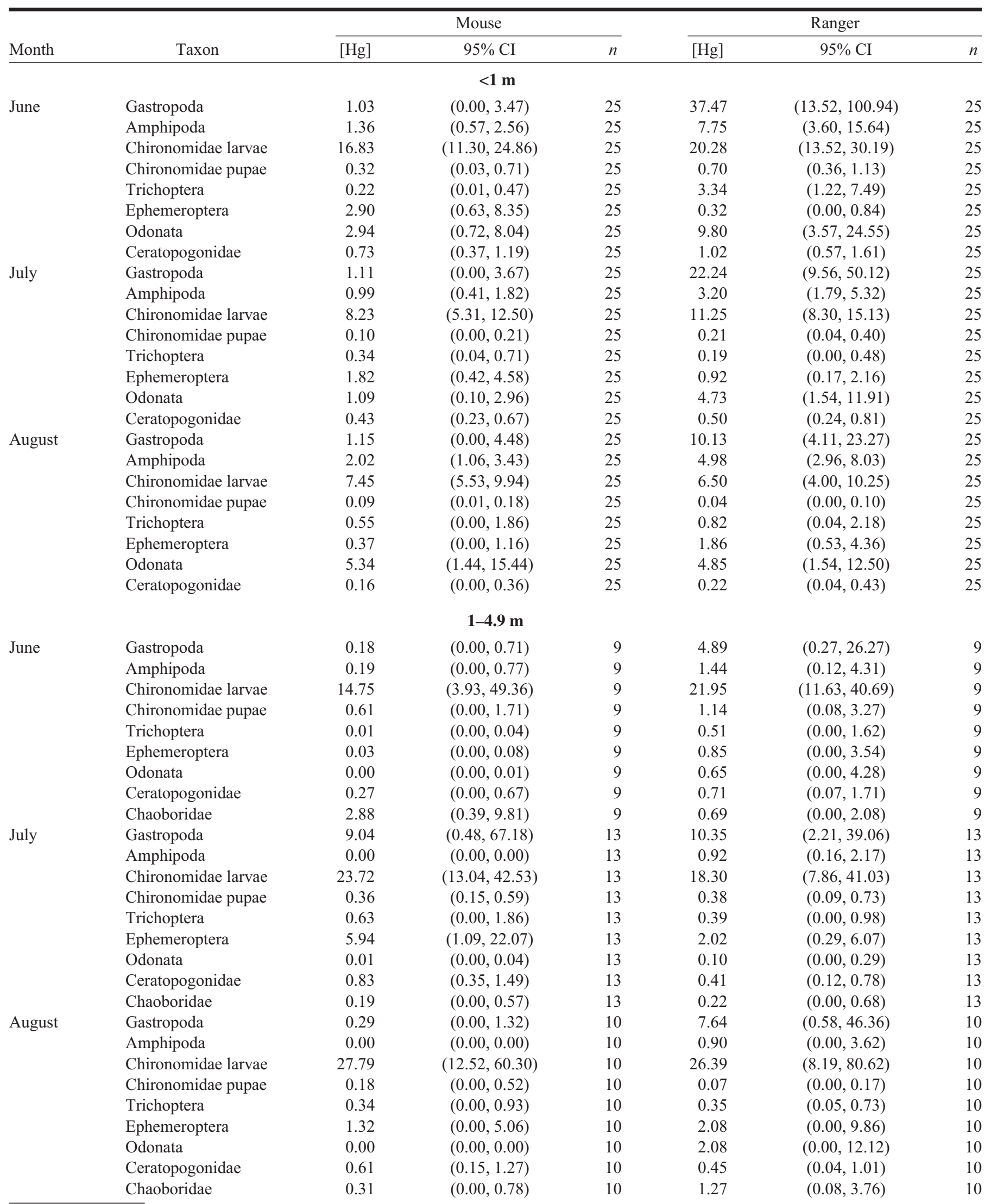


Table 6 (concluded).

\begin{tabular}{|c|c|c|c|c|c|c|c|}
\hline \multirow[b]{2}{*}{ Month } & \multirow[b]{2}{*}{ Taxon } & \multicolumn{3}{|c|}{ Mouse } & \multicolumn{3}{|c|}{ Ranger } \\
\hline & & {$[\mathrm{Hg}]$} & $95 \% \mathrm{CI}$ & $n$ & {$[\mathrm{Hg}]$} & $95 \% \mathrm{CI}$ & $n$ \\
\hline \multicolumn{8}{|c|}{ 5-9 m } \\
\hline & Ceratopogonidae & 0.13 & $(0.00,0.48)$ & 10 & 0.08 & $(0.00,0.22)$ & 13 \\
\hline & Chaoboridae & 3.02 & $(0.97,7.24)$ & 10 & 1.51 & $(0.29,3.89)$ & 13 \\
\hline July & Chironomidae larvae & 13.98 & $(8.68,22.19)$ & 15 & 57.62 & $(30.99,106.41)$ & 13 \\
\hline \multirow[t]{3}{*}{ August } & Chironomidae larvae & 6.26 & $(3.06,12.00)$ & 15 & 42.70 & $(21.68,83.22)$ & 13 \\
\hline & Ceratopogonidae & 0.00 & $(0.00,0.00)$ & 15 & 0.00 & $(0.00,0.00)$ & 13 \\
\hline & Chaoboridae & 2.25 & $(1.66,2.98)$ & 15 & 5.70 & $(2.69,11.17)$ & 13 \\
\hline
\end{tabular}

Fig. 3. Cumulative $\mathrm{Hg}$ consumption rates for Mouse Lake (A) yellow perch (YP), pumpkinseed (PKS), and golden shiner (GS) and (B) white sucker (WS) during 1 June to 31 August 1992.
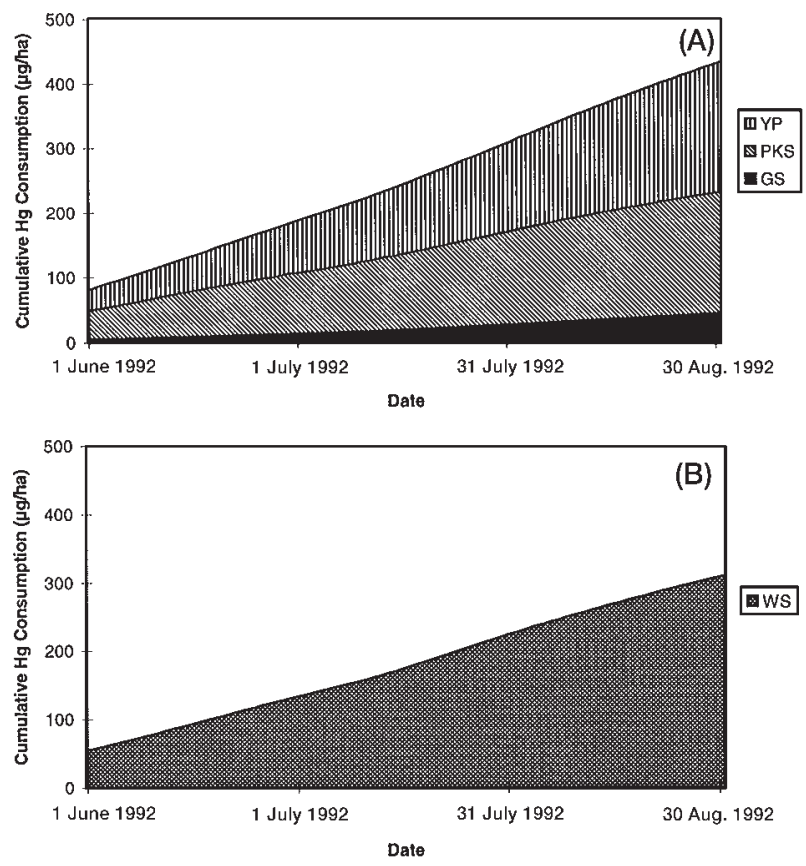

As a result, individuals in the Mouse Lake benthos were larger and had generally higher $\mathrm{Hg}$ concentrations in comparison with those in Ranger Lake. This is in agreement with the positive relationship between $\mathrm{Hg}$ concentration and body size found in other aquatic invertebrates (Parkman and Meili 1993). Furthermore, the larger invertebrate predators found in Mouse Lake would likely more often forage on larger prey and thus would be exposed to more $\mathrm{Hg}$ because of the biomagnification effect of MeHg (Meili 1991a, 1991b). Lastly, the Ranger Lake fishes, which had cohorts with larger individuals, were more likely to feed on larger benthic invertebrates, because they are more profitable food items, thus leaving smaller benthos that tend to have smaller Hg concentrations (Morin 1984; Parkman and Meili 1993).

The fraction of $\mathrm{MeHg}$ in fishes $(\sim 100 \%)$ is higher than in benthic invertebrates (Hildebrand et al. 1980; Bloom 1992). Although the fraction of $\mathrm{Hg}$ as $\mathrm{MeHg}$ in benthos was not
Fig. 4. Cumulative $\mathrm{Hg}$ consumption rates for Ranger Lake (A) yellow perch (YP), smallmouth bass (SMB), pumpkinseed (PKS), largemouth bass (LMB), and golden shiner (GS) and (B) white sucker (WS) during 1 June to 31 August 1992.
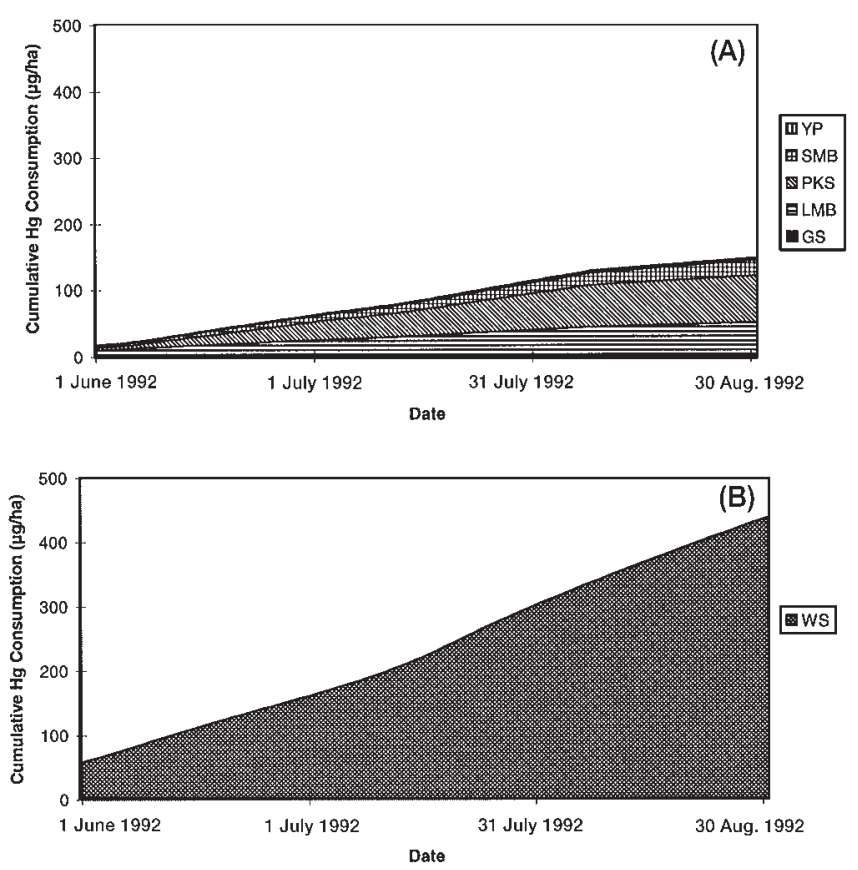

measured in the present study, values in similar benthic invertebrate taxa have been reported in other studies ranging from $<1$ to $100 \%$. Hildebrand et al. (1980) and Huckabee et al. (1979) reported mean percentages of $\mathrm{MeHg}$ in benthic invertebrate taxa to be 55 and $76 \%$, respectively, and Parkman and Meili (1993) found that zooplankton had a median value of $65 \%$. Although the fraction of $\mathrm{MeHg}$ in invertebrates seems not to be as high as in fishes, it is of foremost importance because it is the form of $\mathrm{Hg}$ that biomagnifies up the food chain (Gardner et al. 1978).

Significant ecological impacts of fish predators on benthos have been well documented (Post and Cucin 1984; Keller et al. 1990; Feltmate and Williams 1991). The presence of piscivores in Ranger Lake, coincident with the lower populations of benthivorous fishes, has resulted in lower net predation on the benthos (Wong 1995). This, in turn, has resulted in the 
significantly higher total benthic invertebrate biomass observed in Ranger Lake, as compared with Mouse Lake (Wong 1995). As a consequence, the benthic invertebrate $\mathrm{Hg}$ pools were significantly higher in Ranger Lake in comparison with Mouse Lake. This led to total Hg pools in Ranger Lake that were up to 2.7 times higher than in Mouse Lake in the shallow zone and up to 3.9 times higher in the 5.0-9.0 $\mathrm{m}$ depth zone.

Despite the higher $\mathrm{Hg}$ pools in benthic invertebrates in Ranger Lake, the total $\mathrm{Hg}$ consumed by all fish species via benthos was higher in Mouse Lake. The transfer of $\mathrm{Hg}$ from benthos to fishes was consistently higher in Mouse Lake. This was attributed to the higher consumption rates by fish in Mouse Lake (Wong 1995). When the consumption rates of $\mathrm{Hg}$ were considered without white suckers, the difference was even more evident. In Mouse Lake, the total $\mathrm{Hg}$ consumed by fishes via the benthos averaged 2.7 times higher during June -August and was up to 3.6 times higher (August). This was reflected in the higher $\mathrm{Hg}$ concentrations found in Mouse Lake fishes (B. Petri, Department of Biology, York University, North York, Ont., personal communication). Omitting white suckers from the analysis of consumption rates by fishes allowed for a more accurate determination of where the differences lie. Although white suckers do consume benthos, they usually were observed at depths $>1.0 \mathrm{~m}$ in Mouse and Ranger lakes, as in other studies (Tremblay and Magnan 1991; E. Demers, personal observation). Furthermore, the largebodied white suckers that made up the majority of the white sucker populations in both lakes tended to remain farther offshore (Chen and Harvey 1995). Consequently, differences found in the littoral zone can be attributed to benthivorous fish species other than white suckers. These included yellow perch and pumpkinseed, species that were primarily benthivorous in this study, and in others (Etnier 1971; Sadzikowski and Wallace 1976).

We conclude that a fish community that has a high population of benthivorous species can lead to higher rates of $\mathrm{Hg}$ cycling from benthos to fishes, and thus, higher $\mathrm{Hg}$ concentrations in fishes. It is these differences in fish trophic structures between lakes that may be a potential source of the variation seen in $\mathrm{Hg}$ consumption rates, and thus, $\mathrm{Hg}$ concentrations in fishes. Furthermore, differing fish community structures also can affect $\mathrm{Hg}$ concentrations and $\mathrm{Hg}$ pools in benthic invertebrates as a result of predatory effects. However, because some of the individual invertebrate biomasses and $\mathrm{Hg}$ concentrations were not significantly higher in Mouse Lake, predation effects cannot explain all of the differences in $\mathrm{Hg}$ concentrations. Our knowledge of metal bioaccumulation in invertebrates is very limited and it is likely that species-specific processes (e.g., uptake and depuration rates) also are acting upon these invertebrate species (Wren and Stephenson 1991). Further research is required to determine the relative importance of this process.

\section{Acknowledgments}

We would like to thank Ron Ingram for providing excellent technical assistance. We also wish to express our gratitude for the review and comments on earlier drafts by Greg Mierle, Martyn Futter, and Andrew Green. Keith Somers, Charles Ramcharan, Ian Hogg, Nick Collins, Dave Anstey, and numerous members of the Dorset Research Centre also provided helpful advice. Funding for this project was provided by the Natural Sciences and Engineering Research Council of Canada and the Ontario Ministries of the Environment and Natural Resources. Additional funding was provided by a University of Toronto Open Fellowship to A.H.K.W.

\section{References}

Albers, P.H., and Camardese, M.B. 1993. Effects of acidification on metal accumulation by aquatic plants and invertebrates. 1. Constructed wetlands. Environ. Toxicol. Chem. 12: 959-967.

Allard, M., and Stokes, P.M. 1989. Mercury in crayfish species from thirteen Ontario lakes in relation to water chemistry and smallmouth bass (Micropterus dolomieui) mercury. Can. J. Fish. Aquat. Sci. 46: 1040-1046.

Armstrong, F.A.J., and Hamilton, A.L. 1974. Pathways of mercury in a polluted northwestern Ontario lake. In Trace metals and metalorganic interactions in natural waters. Edited by P.C. Singer. Ann Arbor Science Publishers Inc., Ann Arbor, Mich. pp. 131-156.

Bloom, N.S. 1992. On the chemical form of mercury in edible fish and marine invertebrate tissue. Can. J. Fish. Aquat. Sci. 49: 1010-1017.

Bodaly, R.A., Hecky, R.E., and Fudge, R.J.P. 1984. Increases in fish mercury levels in lakes flooded by the Churchill River diversion, northern Manitoba. Can. J. Fish. Aquat. Sci. 41: 682-691.

Campbell, P.G.C., and Stokes, P.M. 1985. Acidification and toxicity of metals to aquatic biota. Can. J. Fish. Aquat. Sci. 42: 2034-2049.

Chen, Y., and Harvey, H.H. 1995. Growth abundance, and food supply of white sucker. Trans. Am. Fish. Soc. 124: 262-271.

Cromar, G.L., and Williams, D.D. 1991. Centrifugal flotation as an aid to separating invertebrates from detritus in benthic samples. Hydrobiologia, 209: 67-90.

Etnier, D.A. 1971. Food of three species of sunfishes (Lepomis, Centrarchidae) and their hybrids in three Minnesota lakes. Trans. Am. Fish. Soc. 100: 124-128.

Evans, R.D. 1986. Sources of mercury contamination in the sediments of small headwater lakes in south-central Ontario, Canada. Arch. Environ. Contam. Toxicol. 15: 505-512.

Feltmate, B.W., and Williams, D.D. 1991. Evaluation of predator-induced stress on field populations of stoneflies (Plecoptera). Ecology, 72: 1800-1806.

Fitzgerald, W.F., and Clarkson, T.W. 1991. Mercury and monomethylmercury: present and future concerns. Environ. Health Perspect. 96: $159-166$.

France, R.L. 1987. Calcium and trace metal composition of crayfish (Orconectes virilis) in relation to experimental lake acidification. Can. J. Fish. Aquat. Sci. 44(Suppl. 1): 107-113.

Futter, M.N. 1994. Pelagic food-web structure influences probability of mercury contamination in lake trout (Salvelinus namaycush). Sci. Total Environ. 145: 7-12.

Gardner, W.S., Kendall, D.R., Odom, R.R., Windom, H.L., and Stephens, J.A. 1978. The distribution of methyl mercury in a contaminated salt marsh ecosystem. Environ. Pollut. 15: 243-251.

Hewett, S.W., and Johnson B.L. 1992. Fish bioenergetics model 2. Univ. Wis. Sea Grant Inst. Tech. Rep. No. WIS-SG-92-250, University of Wisconsin, Madison, Wis.

Hildebrand, S.G., Strand, R.H., and Huckabee, J.W. 1980. Mercury accumulation in fish and invertebrates of the North Fork Holston River, Virginia and Tennessee. J. Environ. Qual. 9: 393-400.

Huckabee, J.W., Elwood, J.W., and Hildebrand, S.G. 1979. Accumulation of mercury in freshwater biota. In The biogeochemistry of mercury in the environment. Edited by J.O. Nriagu. Elsevier/North-Holland Biomedical Press, New York. pp. 277-302.

Jackson, T.A. 1988. Accumulation of mercury by plankton and benthic invertebrates in riverine lakes of northern Manitoba (Canada): importance of regionally and seasonally varying environmental factors. Can. J. Fish. Aquat. Sci 45: 1744-1757. 
Keller, W., Molot, L.A., Griffiths, R.W., and Yan, N.D. 1990. Changes in the zoobenthos community of acidified Bowland Lake after whole-lake neutralization and lake trout (Salvelinus namaycush) reintroduction. Can. J. Fish. Aquat. Sci. 47: 440-445.

MacCrimmon, H.R., Wren, C.D., and Gots, B.L. 1983. Mercury uptake by lake trout, Salvelinus namaycush, relative to age, growth, and diet in Tadenac Lake with comparative data from other precambrian shield lakes. Can. J. Fish. Aquat. Sci. 40: 114-120.

Mathers, R.A., and Johansen, P.H. 1985. The effects of feeding ecology on mercury accumulation in walleye (Stizostedion vitreum) and pike (Esox lucius) in Lake Simcoe. Can. J. Zool. 63: 20062012.

McNicol, D.K., Mallory, M.L., Mierle, G., Scheuhammer, A.M., and Wong, A.H.K. 1997. Leeches as indicators of dietary mercury exposure in non-piscivorous waterfowl in central Ontario, Canada. Environ. Pollut. 95: 177-181.

Meili, M. 1991a. Mercury in forest lake ecosystems - bioavailability, bioaccumulation and biomagnification. Water Air Soil Pollut. 55: 131-157.

Meili, M. 1991b. In situ assessment of trophic levels and transfer rates in aquatic food webs, using chronic $(\mathrm{Hg})$ and pulsed (Chernobyl ${ }^{137} \mathrm{Cs}$ ) environmental contaminants. Verh. Int. Ver. Limnol. 24: 2970-2975.

Merritt, R.W., and Cummins, K.W. 1978. An introduction to the aquatic insects of North America. Kendall/Hunt Publishing Company, Dubuqe, Iowa.

Mierle, G. 1990. Aqueous inputs of mercury to Precambrian Shield lakes in Ontario. Environ. Toxicol. Chem. 9: 843-851.

Mierle, G., and Ingram, R. 1991. The role of humic substances in the mobilization of mercury from watersheds. Water Air Soil Pollut. 56: $349-357$.

Miskimmin, B.M., Rudd, J.W.M., and Kelly, C.A. 1992. Influence of dissolved organic carbon, $\mathrm{pH}$, and microbial respiration rates on mercury methylation and demethylation in lake water. Can. J. Fish. Aquat. Sci. 49: 17-22.

Morin, P.J. 1984. The impact of fish exclusion on the abundance and species composition of larval odonates: results of short-term experiments in a North Carolina pond. Ecology, 65: 53-60.

OMOE and OMNR. 1991. Guide to eating Ontario sport fish. Ontario Ministry of the Environment and Energy, Toronto, Ont.

Parkman, H., and Meili, M. 1993. Mercury in macroinvertebrates from Swedish forest lakes: influence of lake type, habitat, life cycle, and food quality. Can. J. Fish. Aquat. Sci. 50: 521-534.

Popiel, S. A. 1994. An analysis of the factors regulating growth and recruitment in pumpkinseed (Lepomis gibbosus) sunfish. M.Sc. thesis, York University, North York, Ont.

Post, J. R., and Cucin, D. 1984. Changes in the benthic community of a small Precambrian lake following the introduction of yellow perch, Percaflavescens. Can. J. Fish. Aquat. Sci. 41: 1496-1501.

Ramcharan, C.W., McQueen, D.J., Demers, E., Popiel, S., Rocchi, A.M., Yan, N.D., Wong, A.H.K., and Hughes, K.D. 1995. A comparative approach to determining the role of fish predation in structuring limnetic ecosystems. Arch. Hydrobiol. 133: 389-416.

Rasmussen, J.B., Rowan, D.J., Lean, D.R.S., and Carey, J.H. 1990.
Food chain structure in Ontario lakes determines PCB levels in lake trout (Salvelinus namaycush) and other pelagic fish. Can. J. Fish. Aquat. Sci. 47: 2030-2038.

Rocchi, A.M. 1993. Population structure, size, and age of yellow perch in predator-rich and predator-free lakes. M.Sc. thesis, York University, North York, Ont.

Rodgers, D.W., and Beamish, F.W.H. 1983. Water quality modifies uptake of waterborne methylmercury by rainbow trout. Can. J. Fish. Aquat. Sci. 40: 824-828.

Sadzikowski, M.R., and Wallace, D.C. 1976. A comparison of the food habits of size classes of three sunfishes (Lepomis macrochirus Rafinesque, L. gibbosus (Linnaeus) and L. cyanellus Rafinesque). Am. Midl. Nat. 95: 220-225.

Särkkä, J. 1979. Mercury and chlorinated hydocarbons in zoobenthos of Lake Päijänne, Finland. Arch. Environ. Contam. Toxicol. 8: $161-173$.

SAS Institute, Inc. 1982. SAS user's guide: statistics, 1982 edition. SAS Institute, Inc., Cary, N.C.

Sokal, R.R., and Rohlf, F.J. 1981. Biometry. The principles and practice of statistics in biological research. 2nd ed. W.H. Freeman and Company, New York.

Spry, D.J., and Wiener, J.G. 1991. Metal bioavailabilty and toxicity to fish in low-alkalinity lakes: a critical review. Environ. Pollut. 71: 243-304.

Suns, K., Hitchin, G., Loescher, B., Pastorek, E., and Pearce, R. 1987. Metal accumulation in fishes from Muskoka-Haliburton lakes in Ontario (1978-1984). Water Resources Branch, Ontario Ministry of the Environment.

Tremblay, S., and Magnan, P. 1991. Interactions between two distantly related species, brook trout (Salvelinus fontinalis) and white sucker (Catostomus commersoni). Can. J. Fish. Aquat. Sci. 48: $857-867$.

Verta, M. 1990. Changes in fish mercury concentrations in an intensively fished lake. Can. J. Fish. Aquat. Sci. 47: 1888-1897.

Wiener, J.G., and Stokes, P.M. 1990. Enhanced bioaccumulation of mercury, cadmium and lead in low-alkalinity waters: an emerging regional environmental problem. Environ. Toxicol. Chem. 9: $821-823$.

Wong, A.H.K. 1995. A comparison of the benthic communities and mercury distribution between two lakes of differing fish community structure. M.Sc. thesis, University of Toronto at Scarborough, Scarborough, Ont.

Wren, C.D., and MacCrimmon, H.R. 1983. Mercury levels in the sunfish Lepomis gibbosus, relative to $\mathrm{pH}$ and other environmental variables of the Precambrian Shield Lakes. Can. J. Fish. Aquat. Sci. 40: $1737-1744$.

Wren, C.D., and Stephenson, G.L. 1991. The effect of acidification on the accumulation and toxicity of metals to freshwater invertebrates. Environ. Pollut. 71: 205-241.

Wren, C.D., Scheider, W.A., Wales, D.L., Muncaster, B.W., and Gray, I.M. 1991. Relation between mercury concentrations in walleye (Stizostedion vitreum vitreum) and northern pike (Esox lucius) in Ontario lakes and influence of environmental factors. Can. J. Fish. Aquat. Sci. 48: 132-139. 